\title{
An Analysis of the Importance of National Image Building in the New Era on China's Higher Education
}

\author{
Zhongyao Huang ${ }^{1}$ and Caigang Liu ${ }^{2, *}$
}

\author{
${ }^{1}$ School of Marxism, Guangzhou City Institute of Technology, Guangzhou 510800, China \\ ${ }^{2}$ South China University of Technology, Guangzhou 510641, China \\ *Corresponding author. Email: lcgang@scut.edu.cn
}

\begin{abstract}
At present, China has built the world's largest higher education system with a total student population of more than 40 million. Therefore, it is urgent to train socialist successors with lofty aspirations, international vision and global competitiveness, and to build a national image recognized by college students. National image, the key elements of which include history, reality, national characteristics and people's character, etc., constantly develops with history development. It can be divided into physical image and cultural image. What the physical image represents are the hard power of a country such as politics, economy, military, diplomacy, science and technology and other material power, while the cultural image represents the soft power of a country such as civilization, system, diet and folklore and other spiritual forces. Only by successfully shaping the national image in the new era can we help guide college students to recognize, love, and have faith in the political system, thus promoting the stable development of politics and maintaining the country's healthy development.
\end{abstract}

Keywords: higher education; college students; national image; new era, shaping

\section{INTRODUCTION}

According to The Report of Global Survey of China's National Image in 2019, overseas respondents' overall national impression of China has reached 6.3 points. In the new era, there is still much room for national physical image and cultural images to be improved. With the deepening of economic cooperation under "The Belt and Road" initiative, national physical image and cultural images have been shaped in a more distinct fashion. China's propositions have been listened to by the international community, and Chinese wisdom and solutions have been widely recognized. However, in the new era, it is critically important to ensure the security of national ideology, prevent the western media from distortion and stigmatization, consolidate the dominant position of Marxism in the field of national ideology and cultivate college students' patriotism. Therefore, it is essential for us to actively shape national image recognized by college students. As the COVID-19 epidemic raged around the world, we should further guide them to have national sense of honor and belonging, promote them to assume responsibility in the terms of values, ideals, beliefs, morality and the rule of law, including the family, social and state responsibility, and maintain and build core socialist values with a strong cohesion, centripetal force and leading force, thus fostering socialist builders and successors who have all-round moral, intellectual physical, and aesthetical grounding with a hard-working spirit.

\section{GUIDING COLLEGE STUDENTS TO UNDERSTAND THE COURSE OF HISTORY OF NATIONAL IMAGE}

\subsection{In the early days after the founding of the People's Republic of China, the national image is that Chinese people are independent, industrious, brave and self-sufficient who do not afraid of hegemony and cherish peace.}

In the Seventh National Congress of the Communist Party of China, Mao Zedong stressed in the political report on Coalition Government that, from the current situation, the future that the people should strive for is to "build an independent, free, democratic, unified and prosperous a new China." [1] After the founding of the People's Republic of China, China's national image has changed from an old China which was torn apart by warlords strife under the semi-colonial and semi-feudal society with numb and extremely coward people to a new China with independent, industrious and brave, unified, self-sufficient people who pursue peace and reunification. Through the exploration in the period of socialist construction, the main framework of national fundamental system has gradually taken shape, and Chinese people has been striding forward on the road of "independence, democracy, peace, unity and prosperity" which is identified in the Common Program. 


\subsection{After the reform and opening up, the national image is characterized by it modernization, open and innovation with peaceful rising}

At the beginning of reform and opening up, how to improve the scientific and cultural level of the whole nation and how to build a high level of spiritual civilizations of socialism was on the agenda. Comrade Deng Xiaoping stressed: "Revolution means the liberation of the productive forces, and so does reform. If we do not adhere to socialism, reform and opening up, develop the economy and improve people's lives, we will end up in a dead end." [2] Before the Third Plenary Session of the 11th Central Committee of the Communist Party of China, China was at critical historical moment. Based on China's national conditions, the CPC Central Committee put forward the socialist modernization drive and gave priority to economic development. The socialist modernization drive ushered into a new period and the reform and opening up policy was launched in an active manner. Moderate prosperity evolves from the establishment of the goal, to the overall realization and then to the comprehensive completion in our country. We have achieved rapid economic growth and a dynamic and attractive modern country gradually emerges in front of the world.

\subsection{The image of China in the new era is peaceful and shared development with keeping a foothold on China, embracing the world and orienting towards the future}

The report of the 19th National Congress of the Communist Party of China (CPC) stated that "with long years of hard work, socialism with Chinese characteristics has ushered into a new era, which is a new historical juncture in China's development." [3] From the new road pointed out by comrade Mao Zedong when he discussed "historical periodicity" with Huang Yanpei to the sentiment of "devotion whole-heartedly to my country without considering myself" embraced by President Xi Jinping when he talked with Roberto Fico, speaker of Italian chamber, the Communist Party, against all obstacles, has successively completed the new-democratic revolution and socialist revolution, led the masses to carry out socialist construction and reform and opening up and promoted balanced, coordinated and sustainable economic development, thus fundamentally changing the future and destiny of the Chinese people and nation. The 18th National Congress of the Communist Party of China put forward the development goal of building a strong socialist culture. General Secretary Xi Jinping puts "cultural confidence" into the category of "four self-confidence" and places a higher demand on and richer connotations for the construction of national cultural image.
First of all, since the new era, China has been building the image of a big civilized country in the East. Since Qin Shi Huang, the first emperor of Qin, initiated the centralized mode in agricultural society and unified the writing system, he promoted cultural identity and established ethnic identity. Culture, history and civilization with precise carrier have been passed down from generation to generation until now.

Second, since the new era, China has built the image of a responsible major country. The CPC Central Committee, with Comrade $\mathrm{Xi}$ Jinping as the core, attaches great importance to the outbreak of COVID-19. It immediately prioritized the safety and health of the people at home. In addition, China has paid close attention to and committed to helping countries in need, especially developing countries with weak public health systems. China responds to the global epidemic together with other countries, practices multilateralism, protects vulnerable groups, discards ideological bias, and promotes the building of a community with a shared future for mankind.

Finally, since the new era, China has built the image of a socialist country. Since the founding of new China, we have carried out six stages of poverty alleviation: the general poverty alleviation in the first stage, the rural economic system reform to promote poverty reduction in the second stage, the area development-oriented poverty reduction strategy in the third stage, the integrated crucial strategy for poverty alleviation in the fourth stage, the poverty alleviation for the whole village together with "two wheel-driven" strategy for poverty alleviation in the fifth stage, targeted poverty alleviation to win the battle against poverty in the sixth stage. By current standards, the 832 poverty-stricken counties with the lowest living standards have been lifted out of poverty, eliminating both absolute and regional poverty. Nearly 100 million people living in poverty have seen their incomes rise, and they have been lifted out of poverty thanks to the proactive poverty alleviation efforts of the CPC Central Committee.

\section{GUIDING COLLEGE STUDENTS TO UNDERSTAND THE BASIC POSITIONING OF NATIONAL IMAGE.}

\subsection{It should build the theoretical character of national image with the characteristics of the times, justice and future}

At present, socialism with Chinese characteristics has entered a new era. As General Secretary Xi Jinping has pointed out, "the Communist Party of China is the largest political party in the world." "If you are big, you must assume your due big responsibility." [4] Big means not only in the sense of scale, but also in the sense of capability, which means that China and the Party assume a relatively large responsibility and play a relatively large 
role in building a "community with a shared future for mankind".

\subsection{It should have the basic positioning of building a major socialist country, a major country with oriental civilization and a responsible country}

From the construction of socialist road suited to China's national conditions pointed out by Chairman Mao to the construction of socialism with Chinese characteristics put forward by Comrade Deng Xiaoping, the Communist Party has gradually constructed the socialist road suited to China's national conditions. First of all, China is a big socialist country that will never change. Second, China is a country with a vibrant oriental civilization. Finally, China is a responsible major country that cares about the world. When we won the battle against the coronavirus in Wuhan and achieved periodical victory, the foreign political situation changed profoundly with the outbreak of the epidemic. Some Western politicians and media deliberately fabricated rumors, distorted the reality, exaggerated the facts, repeatedly named the virus after local names and politicized the epidemic, which makes the global fight against the epidemic pessimistic. The public opinion war under the strategic game reflects the will and interests of the state. There is no absolute openness, objectivity, transparency and justice, and it is highly selective and tendentiousness.

\section{GUIDING COLLEGE STUDENTS TO STRIVE FOR BUILDING THE IMAGE OF BIG POWER.}

College students are an important force to maintain national security at present and in the future. The degree of identification with national image directly affects their love for the country. Hu Kaibao, a famous scholar, proposed that national image shaping includes self-shaping and shaping by others. [5] In terms of self-shaping, it is imperative to strengthen its breadth and depth, while in terms of shaping by others, it is difficult to grasp the direction and objective. Other countries know some of the data and achievements about building well-off society in China, but they are not necessarily willing to believe or let their own people know, because this information will have a great pressure on their own country. Thus, they often downplay these achievements and even let their own people know nothing about it.

Since reform and opening-up, especially since the 18th CPC National Congress, China has lifted more than 700 million people out of poverty through targeted poverty alleviation, which demonstrates our institutional advantages and makes China the most effective country in poverty reduction in the world. Works in China, such as $\mathrm{Xi}$ Jinping's Poverty Alleviation Story, Voyage from the
Eighteen Caves, Minning Town, Pursuit of a Better Life, and Poverty Alleviation and Library's Action: A Collection of Cases of Poverty Alleviation by National Libraries, have vividly showed the image of the country and the political party, won social praise and recognition, and enhanced the political identity of the public. However, there are still a small number of college students who pay little attention to the situation at home and abroad, do not understand national policies, have weak awareness of national development and national security, do not have a clear understanding of the plot of the hostile forces, and lack of awareness to maintain political integrity, think in big-picture terms, follow the leadership core, and keep in alignment. According to statistics from Legal Daily, the number of cases involving college students endangering national security is on the rise. How to guide college students to make efforts to build the image of great power, break the western monopoly of the discourse and interpretation power, and strengthen and improve their overall education of national security concept is not only a major issue that the Party Central Committee attaches great importance to, but also an urgent subject that the academic circle needs to study in a profound way and puts forward countermeasures and suggestions.

\subsection{To consolidate and improve the strength of a big country is the basis and key to build the image of a great power.}

In the era of network, the influence of network on college students is self-evident. It is vital to build the national image in the new era. Movies like The Great Motherland, A Journey to the High Road, A Bite of China, National Treasure, Amazing, My Country and The Wandering Earth all play a good role in promoting and building the national image. In the process of building the national image, a variety of data should be listed to show the hard power of the physical image of China since "four comprehensive" strategic blueprint. In addition, it should strengthen and promote the soft power such as food culture, folk phenomenon, local conditions and customs, tourism and beautiful landscape. National security is faced with complex situations and severe challenges, so it is necessary to strengthen the overall national security education, improve college students' awareness of national security and behavioral ability. Building a solid defense line of national security is conducive to cultivating college students' long-term vision, overall concept and dialectical thinking, helping them solve relevant practical problems in their study and life, enhancing their awareness of adversity, thinking of danger in times of peace, and thus realizing comprehensive and free development. 


\subsection{Striving for the international discourse power and reconstructing the international discourse system are the practical requirements on building the image of a great power}

First of all, we should fully grasp and analyze the facts and laws of the reform of international discourse system and the transfer of international discourse power in human history, especially in modern times. After the Second World War, developed countries, in accordance with their own national interests, promoted international institutions, order and rules that constitute their own priorities, and took the initiative to grasp the right of international discourse and international interpretation. Secondly, we should have a deep understanding on the actual situation of the international discourse system under the current international environment, fully study and judge the "international" and "domestic" situations, and avoid the misjudgment caused by the information gap due to information asymmetry. Last, we should unswervingly implement the concept of "a community with a shared future for mankind" proposed by General Secretary Xi Jinping, strengthen solidarity with the governments of major countries and the people of the world, and work together to overcome the epidemic.

\section{CONCLUSION}

To sum up, it requires schools to identify a more precise teaching objective -national image on the basis of specific patriotism according to the laws of the students' growth and cognitive characteristics to cultivate their moral emotion in elementary school, strengthen their ideological basis in junior middle school, improve their political quality in high school and enhance their sense of mission in university. With the change and development of the country, it is extremely important for higher education to cultivate college students' patriotism in building a national image recognized by college students and making them generate a sense of national honor and belonging. In this paper, it first discusses that college students should understand the historical course of national image; then college students should understand the basic positioning of national image; last, college students should work hard for the practice of building the image of a big country. Higher education should strive to train college students to be socialist builders who have all-around moral, intellectual physical and aesthetical grounding with a hard-working spirit and become socialist successors with lofty aspirations, international vision and global competitiveness.

\section{ACKNOWLEDGMENT}

Network Ideological and Political Work Research Project of Guangdong Institutions of High Learning in 2020, Project name: Research on the Communication of Excellent Campus Network Culture Based on College Students Network Community, Project No. GDWL20YB39;

Fundamental Research Funds for the Central Universities of South China University of Technology (Social Sciences), Project name: Study on the Influence of Traditional Cultural Belief on College Students' Spiritual Life, Project No.: C2190860.

\section{REFERENCES}

[1] Selected Works of Mao Zedong (the third vol.) [M]. Beijing: People's Publishing House, 1991:1053.

[2]Selected Works of Deng Xiaoping (the third vol.) [M]. Beijing: People's Publishing House, 1993: p.370.

[3]Selected and Compiled Important Documents Since the 19th National Congress of the CPC (part 1)[Z]. Beijing: Central Party Literature Press, 2019:7.

[4]Xi Jinping: The Governance of China, No. 3 [M].Beijing: Foreign Language Press, 2020:436

[5]Hu Kaibao, Li Jin. On Study of Corpus-Based Translation and Chinese Image: Connotation and Significance [J]. Foreign Languages Research, 2017:4 